\title{
A DATA BANK FOR THE GEOGRAPHICAL ALLOCATION OF FUTURE U.S. ENERGY SUPPLY FACILITIES BY COUNTY
}

\author{
Walter A. Sevian and Salvauur R. Buzzo
}

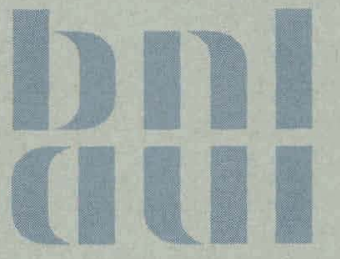

MAY 1977

BIOMEDICAL AND ENVIRONMENTAL ASSESSMENT DIVISION

NATIONAL CENTER FOR ANALYSIS OF ENERGY SYSTEMS

\author{
BROOKHAVEN NATIONAL LABORATORY \\ ASSOCIATED UNIVERSITIES, INC. \\ UNDER CONTRACT NO. EY-76-C-02-0016 WITH THE \\ DIVISION OF TECHNOLOGY OVERVIEW/ENVIRONMENT \\ UNITED STATES DEPARTMENT OF ENERGY
}




\section{DISCLAIMER}

This report was prepared as an account of work sponsored by an agency of the United States Government. Neither the United States Government nor any agency Thereof, nor any of their employees, makes any warranty, express or implied, or assumes any legal liability or responsibility for the accuracy, completeness, or usefulness of any information, apparatus, product, or process disclosed, or represents that its use would not infringe privately owned rights. Reference herein to any specific commercial product, process, or service by trade name, trademark, manufacturer, or otherwise does not necessarily constitute or imply its endorsement, recommendation, or favoring by the United States Government or any agency thereof. The views and opinions of authors expressed herein do not necessarily state or reflect those of the United States Government or any agency thereof. 


\section{DISCLAIMER}

Portions of this document may be illegible in electronic image products. Images are produced from the best available original document. 


\title{
A DATA BANK FOR THE GEOGRAPHICAL ALLOCATION OF FUTURE U..S. ENERGY SUPPLY FACILITIES BY COUNTY
}

\author{
Walter A. Sevian and Salvador R. Bozzo
}

MAY 1977

\author{
BIOMEDICAL AND ENVIRONMENTAL ASSESSMENT DIVISION \\ NATIONAL CENTER FOR ANALYSIS OF ENERGY SYSTEMS \\ BROOKHAVEN NATIONAL LABORATORY \\ ASSOCIATED UNIVERSITIES, INC. \\ UPTON, NEW YORK 11973
}




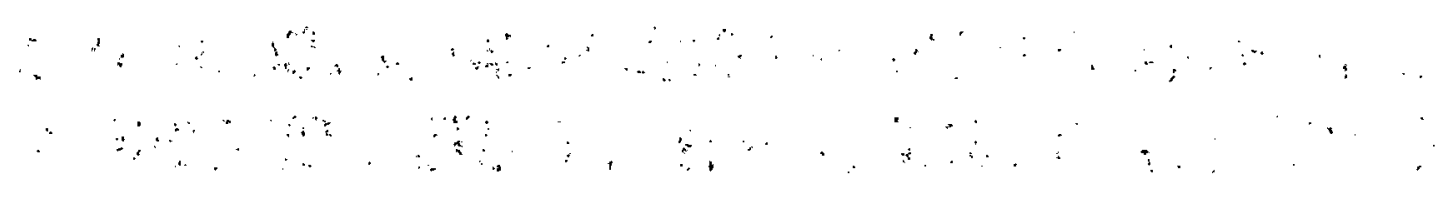

NOTICE

This report was prepared as an account of work sponsored by the United States Government. Neither the United States nor the United States Department of Energy (DDE), nor any of their emplnyees, nor any of their contractons, subcontractors, or their employees, makes any warranty, express or implied, or assumes any legal liability or responsibility for the accuracy, completeness or usefulness of any information, apparatus, product or process disclosed, or represents that its use would not infringe privately owred rights. $\because ; i$

- Printed in the United States of Ariterica Available from

National Technical Information Service

U.S. Department of Commerce

. 5285 Port Royal Road

Springfield, VA 22161

Price: Printed Copy $\$ 4.50$; Microfiche $\$ 3.00$

January 1978

285 copies 
$\underline{\text { PAGE }}$

I INTRODUCTION . . . . . . . . . . . . . . . . . . . 1

II ORGANIZATION OF THE DATA BANK. . . . . . . . . . . . 3

III CONTENTS OF THE DATA BANK. . . . . . . . . . . . . 5

IV APPLICATIONS TO BIOMEDICAL AND ENVIRONMENTAL

ASSESSMENT • • . • • • • • . • • • • • • • • . . 9

TABLES • • . . . . . . . . . . . . . . . 15

REFERENCES • . . . . . . . . . . . . . . . . 27 


\section{INTRODUCTION}

An important step in the construction of a system designed: to assess the biomedical and environmental effects of energy production and consumption, past, present, and future, is the assembly and validation of comprehensive and appropriately disaggregated data banks. Toward this end, considerable Interest has appeared, within the past several years, in the development of technical, environmental, socio-economic, and health effects data banks related to the production and utilization of energy. Many of these data banks have been disaggregated to the county. level. 'A recent contribution to such an effort, given in Reference 1 , is the MEDABA data bank; an information file on health statistics grouped at the county level. as well as about. selected population density classes. Another recent contribution, discussed in Reference 2 , is the COENBU data bank, a county-level atlas of U.S. energy supply and utilization activities. This atlas includes quantities such as fuel-specific energy production and consumption totals by county, as well as total air emissions that are generated by such energy:-activities; for the year $1972 . \cdots$ Since it is designed aroind a recent past year, the atlas develops a description of the near-current effects of energy activities. The data sets that serve as bases for these works represent significant efforts towards the county-level approach to data disaggregation.

Up to the present, no attempt has been made to produce a comprehensive data bank contalning specific sitings of future energy resources and supply process facilities. As a contribution 
toward the analysis and evaluation of the biomedical and environmental effects of future energy systems, a county-level data bank of future U.S. energy supply facilities has been developed and is presented in this paper. This data file attempts to fulfill a requirement for a county-level information source useful in the disaggregation of future energy supply and utilization projections, and the generation of closer links between energy resources, their development and use, and a comprehensive set of the effects of energy consumption. The details of production and end use patterns throughout the energy system can be studied using an energy process-level model such : as ESNS, discussed In Reference 3, and the resulting effects. analyzed using a combination of meteorological models, COENBU, and MEDABA. However, in: order to link these capabilities together, there exists a need for a geographically disaggregated file of future resources and facilities sites applicable to the evaluation of the effects of future energy. scenarios.

$\Lambda$ data filc format was developed, starting from the informillun available in the literature, for each specific facility. The primary sources of information were References 4 and 5 , which contain an inventory of future U.S. energy facility sites out to the year 1985, compiled as of May 1976, although other. information sources (see Reference 6) were also utilized. The data bank will be continually updated to reflect the most recent information gathered from the literature, and many changes have 
already been made using such information. The file format contains such 1.tems as fuel type, process type, year of planned availability, production capacity, employment, and the state and county location for each facility. The formats were planned. to permit expansion of the facilities files as-new and/or revised information becomes available. Also, included in the file format for each facility is a numbered.listing of the data sources.. The actual list of data sources is kept external to the data bank. Several applications programs have also been developed arid utilized for extraction and analyses of portions of the data file. Tables appear in a separate section at the end of this report. II ORGANIZATION OF THE DATA BANK

The key elements in the organization of the data bank are the energy facilities and the county in which a particular facility is to be located. The energy facility is classified according to (a) specific fuel type, (b) activity type (e.g. extraction), and (c) a process-type where applicable, such as slurry pipeline for the distribution of coal. A chart showing this facilities classification system is presented in Table 1. Arranged vertically along the left gide nf the chart are the fuel types (with the exception of railroads) and along the upper portion of the page are the activities present in all the fuel supply cycles. A mark in the activity column specifies that particular fuel-activity combination are avallable in the data bank. 
When a facility is present in a particular county, an identification card is required in the data bank. The format of the identification card is shown in Figure l. Elght specific. fields of information appear on the card.: A sequence number is assigned, for purposes of internal management, in . Columns $1-6$. The next two columns, 7-8, are left blank and are to be used to indicate either modifications to a particular record or the cntry nf a new record. Column 9 contains a. card type 1dentifier, which is sel: to 1 for an identification card. Columis $(10,1.7),(12,13)$, and $(14,15)$ contain a fuel. type code, an activity-type code, and a process-type code, respectively, that are assigned to the. particular facility present within the county. The last two fields, Columns $(16,17)$ and $(18-20)$ contain the state and county condes that. specify the geographical location of the facility. The data descriptions and data formats appearing on the identification card are summarized in Table 2 .

Following the identification card that locates a particular facility type, the facility cards appear. Since the formats of the facility cards differ for each particular facility, the specific formats are presented in the following section, along with complete descriptions of each facility card, i.e., the contents of the data bank. Th1s section concludes with a general discussion of the organization of the facilities cards. 
Facilities in the data bank are classified into three types (a) new, (b) currently operating and (c) expansions to currently operating. All facilities cards contain the same information in Columns $1-9$ as the identification card. For a facility card, the card type is set equal to 2.. The next entry is always a year, future or current, depending upon whether or not the facility is either (a) brand new or a future expansion of existing capacity. or (b) an entry representing the existing capacity itself: All currently active facilities, when included, are given for a base year, usually 1974 or 1975. When 1 t 1 s determined that a planned facility has been cancelled, the number 9999 appears in place of the year entry.

Following the year entry on each facility card are entries that give process descriptions where either applicable or required, process capacities, levels of operating employment, state and counties of destination for pipelines, and other information.: Also included is a certainty code reflecting a judgment applied to the level of development of the project and an assessment of potential future uncertainties regarding its initiation and/or completion. The specifics of the conde and the formats of the specific facilities are given in the next section.

\section{CONTENTS OF THE DATA BANK}

A complete list of the future energy supply projects appearing in the data bank is given in Table 3. To the right of each project are the assigned facility: codes., by fuel type and by activity type, that appear on the identification cards. When more than one fuel type or activity is 1nvolved in the project classification, it is 
so indicated. Table 3 also contains the activity codes corresponding to the activity headings that are shown in Table 1 for the general facilities classification system.

Summarized in Tables 4 through 21 are the data descriptions and data formats appearing on the facility cards. Since each facility requires a unique set of information, each card is discussed separately.

'l'able 4 contains the information provided for future coal mine facilities. The mine type, strip or underground, is given, along with the planned production. Employment (operating only) is given, along with an analysis of the coal. The analysis includes moisture content, ash content, sulfur content (low and high or average for each facility) and average heat content in Btu/lb.

Descriptions and formats for future coal conversion facilities are given in Table 5, A process description is included, along with a process code for retrival pruposes. The planned productive. capacity is given, and the units of: capacity for each process, along with the code type, are indicated as a footnote to Table 5 .

Table 6 contains the facility data for future coal slurry pipelines.. GIven are the annual capacity, planned length, pipe diameter, and water requirements. A description is also included for the source of the water.

Data for future planned oll refineries is presented in Table 7. The anticipated throughput volume is given, for either new refineries or additions to current refineries that will boost this capacity. 
Summarized in Table 8 is data for new oil and gas pipelines. The state and county codes of destination are given, along with the planned length and pipeline diameter. A code is given to denote an interstate or intrastate addition.

Table 9 contalns data on new natural gas processing facilities. The planned throughput in thousands of cubic feet per day are indicated.

Natural gas storage facilities are described in Table 10. Included in the data are a description of the facility type, the capacity, the units of capacity, and the peak load deliverability:

Planned uranium mines are described in Table 11 . A code is given for the mine type, and a productive capacity is indicated.

Table 12 gives information on future uranium mills. The process type is described, and the planned productive capacity is given. Future uranium enrichment facilities are described in Table 13. A process type is presented, and the planned capacity is given.

Table 14 contains the data descriptions for future electric power plants. The planned fuel type is given as a code, as well as the amount of fuel use in tons for a coal-fired plant. The installed rpapsity of the planned power plant is also given.

Potential geothermal facilities are described in Table 15. The capacity of the facility is indicated in different units, depending on whether the faclitty is planned as a source of electricity or direct heat.

Solar energy facilities are described in Table 16, with the capacity given in MWe for electric power plants. 
Table 17 lists the data elements included for waste-to-fuel conversion facilities. The plant and feedstock type are given, along with the planned capacity and the units of capacity.

Table 18 describes future ofl shale project data. A mine type is given as a code to denote whether the extraction is strip, underground, or in-situ. The planned capacity: is given in $10^{3}$. barrels per day.

Future tar sands projects are described by the data elements appearing in Table 19. The process type is described, and the planned capacity is indicated.

Table 20 gives data elements for future rallroad construction planned for the transportation and distribution of fuels. A state and county of destination is given, with the identification card containing the state and county of origin. The length of the proposed line is given, and a type (spur or mainline) is described.

Future terminal facilities data elements are given in Table 21. The facility type is described, and a code for the fuel.type to be handled is given. The sapacity and the unito of capacity arc uluo specified.

The formats for the future energy facilities contained in l'ables 4-2i can be readily adapted to include current operating facilities. In a few special cases where a facility represented an expansion to existing capacity, both the current facility and its expansion where added to the data bank on separate records. However, such information is not intended to be exhaustive. It is intended In the future to update the data bank with such an exhaustive list. 
Locations for such current facilities as oll refineries, coal preparation plants, natural gas processing plants, offshore o1l platforms, coke ovens, petrochemical plants, cement factories, copper smelters, etc., can be codified and included in the data bank for purposes of retrieval and utilization in analyses of the consequences of energy production and consumption. IV APPLICATIONS TO BIOMEDICAL AND ENVIRONMENTAL ASSESSMENT

In this section, a system that has been developed incorporating the data bank of future energy supply facilities for the analysis of the biomedical and environmental consequences of energy production and consumption will be presented.

The development and utilization of a data bank and its associated models must account for the nature of the applications to be addressed when a level of disaggregation is chosen for the data. As an example, the ESNS model (see References 3), which is a demand-driven energy process model, is disaggregated by process and fuel type. The energy process is the lowest significant level of disaggregation associated with this model. At this level, ESNS generates, along with other results, resources consumed in any year of interest alung with a comprehensivc set of air and water emissions, from both fossil and radiological sources, for all current and a complete set of new technology processes: However, the model does not assign the emissions in space, i.e., it is assumed that resources, emissions and end uses are spatially 
independent, and intergeographical transfers of energy, pollutants, and othër environmental damages are not avallable. This limitation to ESNS has been recognized and will be corrected by regionalization.

The problem of adding a geographical dimension to ESNS can be solved by either (a) running the model as a U.S. national model and then disaggregating the resulting outputs to the lowest level of significance required for the particular application, or (b) running the model for each of a complete set of predetermined geographical areas of interest (such as AQCR, Census). Solution (b). is only partial, since the different regions are flxed, yielding specific levels of accuracy. For such predetermined regions, it is not possible to assign the effects of energy production and consumption in. space with the accuracy required for a clear preception of the "communities" receiving the impacts. Solution (a) implies that after the national model is run, a secondary file of information is needed to allocate in space the resources required and the residuals produced by any ESNS model run. With the county as the chosen level of spatial disaggregation, the secondary file must have the capability to provide information at any level of aggregation at or above the county level. One of the components of this secondary file is the county-level facilities sites data bank previously discussed. 
The outputs of the current ESNS models can be expressed as a set of matrices $R_{n}(I, J)$, where

$$
\begin{aligned}
& R_{n} \text { is the residual of the } n^{\text {th }} \text { type } \\
& I \text { is the process-type index } \\
& J \text { is the fuel-type index }
\end{aligned}
$$

The geographic dimension is incorporated into the ESNS outputs by defining the residuals sets $R_{n}(I, J, K)$, where $R_{n}, I, J$ are as above, but $K$ represents the spatial variable, here assumed to be the county. Although the county is generally the logical choice of spatial variable when an allocation of the consequences of energy production and consumption to communities is required, $1 \mathrm{t}$ is not the sole unit of interest. For example, let $R_{n}$ be particulate matter from private automobiles. The county would be the choice for the level of significance for this effect, $1 . e$. , it is unlikely that such emissions would find receptors in counties other than those in which they were generated. But, if $R_{n}$ is the sulfur dioxide emission from a coal-fired power plant, longrange transport and chemical transformations involving $\mathrm{SO}_{2}$ would be taken into account in a judgmental approach to a level assignment. Finaily, if $R_{n}$ is the primary fuel loss from a PWR nuclear plant, the level assignment would be arbitrary since the value would be nearly indentical for all PWR nuclear plants in the U.S. A numerical scale for such geographical levels of significance will be proposed for assignment to the process-level residuals generated by the ESNS model. 
Assignment of specific geographical levels of significance for the process-level residuals requires among others the following considerations (a) an appraisal of the current understanding of the geographic range of effect, if any, of the residuals. 'Problems of data quality and availability can be handled by carefully noting in the classification assignments both the actual and required levels of avallability. As an example, consider a 1985 ESN3 seendrio which generates a given requirement for electricity from coal. The facilities file. will provide the sites for all coal-fired electric power plants planned to bc online in the vear.:. Once the sites are provided, the source of the coal is determined. The method of determination might be simply closest resource proximity to: the power plant,.. although more complex methods involving several variables will. be formulated and adapted. Once the site of the resource base for the power plant is located, an intormation file is searched that contains all the coal characteristics available for the particular site. One characterist1c of particular concern is the silfur contant of the coal, and this value should be available for every site. $\because$ If in some: cases it is not, then a default value of necessarily lesser accuracy would he chusen. This value could be either the average sulfur contcnt of all avallable. values for the state containing the resource site, oi the rlational average value. Similar arguments follow for such characteristics as ash content and heating value. Of course, any changes to these values resulting from the blending and preparation; 
of coals in the resource bases would also be incorporated: 'When the sulfur content of the coal is determined, the $\mathrm{SO}_{2}$ emission from the sited power plant' is known:

The geographtc code shown below is suggested. Th1s code will be assigned to all ESNS process-level residual outputs.

$\begin{array}{lll}\text { GEOGRAPHIC LEVEL } & & \text { CODE } \\ \text { TRANSNATIONAL } & & 1 \\ \text { NATIONAL } & ; & 2 \\ \text { STATE AGGREGATE } & \vdots & 3 \\ \text { STATE } & & 4 \\ \text { COUNTY AGGREGATE } & & 5 \\ \text { COUNTY } & 6 \\ \text { SUBCOUNTY } & & 7\end{array}$

Once the process-level effects are assigned a geographical dependency, the facilities file will be used with a special allocation program to assign the ESNS effects to the appropriate geographic level.

The ESNS residuals generated by a given mix of energy technologies will be available for every geographical level of significance from the county upward. Then, the MEDABA riles (see Reference 1) will be applied to selected county groupings based on projected future population levels within the groupings to generate estimations of populations at risk and estimations of future health effects for the ESNS scenario. 
In summary, the following steps in the system just discussed are outlined:

(a) specify the mix of energy technologies for ESNS

(b) run the national energy system (ESNS)

(c) using the facilities files, site the needed facilities

(d) using ESNS data files, generate emissions for all sites

(e) compare site totals with available process totals

(f) allocate emieriono to the county (u' other) level

(g) develop county aggregates by projected populalion erowth

(i) using MEDABA, assign estimated health effects to the aggregates .

A flowchart showing the key elements in the system is given in Table 22. Elements of the current ESNS and MEDABA systems are indicated. 
TABLE 1

FACILITIES CLASSIFICATION SYSTEM

23

4

CONVERSION

CONVERSION

6

7

\begin{tabular}{l|l|l|l|l|l|l} 
EXTRACTION & TRANSPORTATION & PROCESSING & (NONELECTRIC) & (ELECTRIC) & DISTRIBUTION & STORAGE \\
\hline
\end{tabular}

COAL

OIL (CRUDE)

NATURAL GAS

1

它

1

URANIUM
$\mathrm{X}$

OIL (SHALE) X

GEOTHERMAL $\quad \mathrm{X}$

RAILROALS

TAR SANIS

$\mathrm{X}$

WASTE

ELECTRICITY

SOLAR
$\mathrm{X}$ $\mathrm{x}$

$\mathrm{x}$

$\mathrm{X}$

$\mathrm{X}$

$\mid \begin{aligned} & x \\ & x \\ & x \\ & x\end{aligned}$

$\mathrm{X}$

\begin{tabular}{l|l} 
DISTRIBUTION & STORAGE \\
\hline
\end{tabular}

$\mathrm{X}$

$\mathrm{X}$

$\mathrm{X}$

$\mathrm{X}$

$\mathrm{X}$

X

$\mathrm{X}$ 


\section{TABLE 2}

\section{DATA ELEMENT DESCRIPTIONS AND FORMATS FOR THE IDENTIFICATION CARD}

\section{ELEMENTS}

(1) Sequence Number

(2) Modification Flag

(3) Cara Type (=i tor Thentification)

(4) Fuel Type Code

(5) Activity Type Code

(6) Process Type Code

(7) State Code

(8) County Code
FORMATS

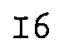

I2

II

I2

I2

I2

I2

I3 


\section{TABLE 3}

FUEL AND ACTIVITY CLASSIFICATIONS FOR

FUTURE ENERGY PROJECTS

\section{FACILITY CODES}

FUEL

COAL:

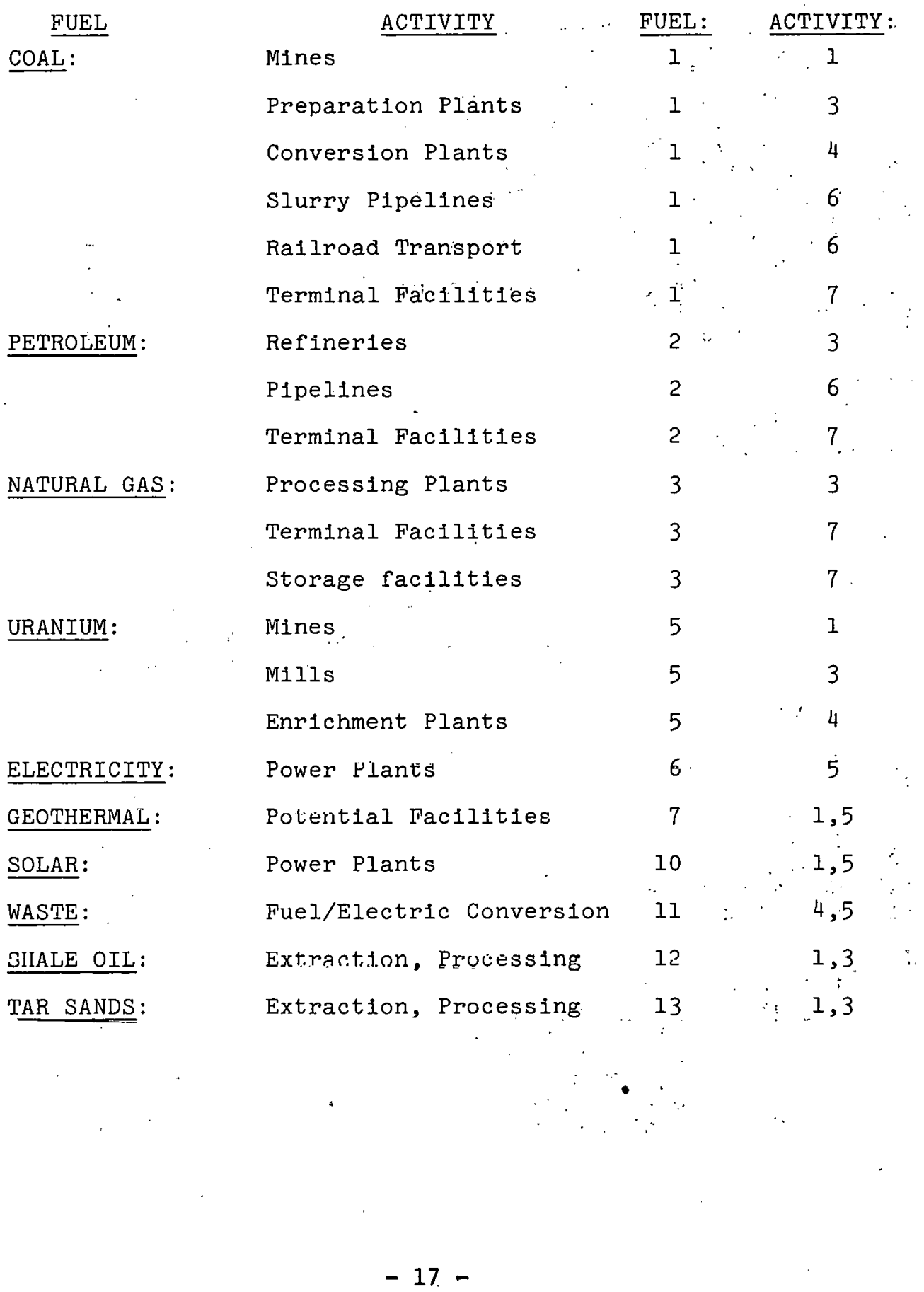

PETROLEUM:

NATURAL GAS:

URANIUM:

GEOTHERMAL :

SOLAR:

WASTE:

SIIALE OIL:

TAR SANDS:

FUEL: ACTIVITY:

$1 \cdot 3$

$1: 4$

1.

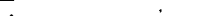

i. 7 


\section{DATA ELEMENT DESCRIPTIONS AND FORMATS FOR THE FACILITY: COAL MINES}

ELEMENT DESCRIPTIONS

(1) Sequence Number

(2) Modification Flag

(3) Card Type (=2 for facility)

(4) Current (or future) Year

(5) Mine Tyne a

(6) Production 6 (current or planned)

(7) Employment (current or planned)

(8) Certainty Code

(9) Molsture Content c (low)

(10) Mo1sture Content $c$ (higher average)

(1i) Ash Content. c (1nw)

(12) Ash Content $c$ (high or average)

(13) Sulfur Content c (low)

(14) Sulfur Content c (high or average)

(15) Heat Content d

(16) Data Sources
FORMATS

I6

I2

II

I4

$1 \dot{2}$

F5.2

I5

II

F4.1

F4.1

F4. 1

F4.1

F4.1

F4.1

I8

1012

Notes:

(a) 01 for strip, 02 for underground

(b) in $10^{6}$ TONS/YEAR

(c) in percent by weight

(d) in Btu/lb.

TADLE 5

DATA ELEMENT DESCRIPTIONS AND FORMATS

FOR THE FACILITY: COAL CONVERSION PLANTS

\section{ELEMENT DESCRIPTIONS}

(1)-(3): Identical to those appearing on Table 4

(4) Future Year

(5) Process Descrintion

(6) Process Code a

(7) Capacity a

(8) Employment

(9) Certainty Code

(10) Data Sources

FORMATS

I4

A10

II

F5.

I5

II

IOI2

Nutco:

(a) the process codes and corresponding units of capacity are:

\begin{tabular}{|c|c|c|}
\hline 1 & $\frac{\text { Process Description }}{\text { high-Btu gasification }}$ & $\frac{\text { Unfts of Capaci }}{10^{6} \text { cu.ft./day }}$ \\
\hline 2 & ammonia production & tons/day \\
\hline 3 & Iiquefaction & 103 barrele, day \\
\hline 4 & Low-Btu gasification & cu.ft./day \\
\hline 5 & 1n-situ gasification. & $10^{6}$ cu.ft./day \\
\hline
\end{tabular}




\section{TABLE 6}

DATA ELEMENT DESCRIPTIONS AND FORMATS

FOR THE FACILITY: COAL SLURRY PIPELINES

\section{ELEMENT DESCRIPTIONS}

HORMATS

(1)-(3): Identical to those appearing on Table 4

(4) Year (initial operating date)

(5) State Code of Destination

(6) County Code of Destination

(7) Capacity a

(8) Length

(9) Pipe Diameter ${ }^{c}$

(10) Water Requirements d

(11) Water Source

(12) Employment

(13) Certainty Code

(14) Data Sources

I4

I2

13

F5.0

14 .

I2

I5

Al0

I5

II

$10 \mathrm{I2}$

Notes:

(a) in $10^{6}$ tons/yr

(b) in miles

(c) in inches

(d) in 103 barrels/day

DATA ELEMENT DESCRIPTIONS AND FORMATS

FOR THE FACILITY: OIL REFINERIES

\section{ELEMENT DESCRIPTIONS}

FORMATS

(1)-(3): Identical to those appearing on Table 4

(4) Current (or future) Year

(5) Current (or additional) Throughput a

(6) Employment

(7) Certainty Code

(8) Data Snurces

Notes:

(a) 1 in $10^{3}$ barrels/day 
TABLE 8

DATA ELEMENT DESCRIPTIONS AND FORMATS

FOR THE FACILITY: OIL AND GAS PIPELINES

ELEMENT DESCRIPTIONS

FORMATS

(1)-(3): Ident1cal to those appearing on Table 4

(4) Year

(5) State Code of Destination

(6) County Code of Destination

(7) Length a

(8) Diameter. b

(9) Employment

(10) Intrastate/Interstatc code 6

(1.i.) Gertainty Code

(12) Data Sources

Notes:

(a). In miles

(b) in inches

(c) 1 for intrastate, 2 for interstate

TABLE 9

DATA ELEMENT DESCRIPTIONS AND FORMATS

FOR THE FACILITY: NATURAL GAS PROCESSING PLANTS

ELEMENT DEJCRIPTIÜISS

FORMATS

(1)-(3): Identical to those appearing on Table 4

(4) Year (initial operating date)

(5) Flanned Thro'ughput a

(i) Employment

(7) Certainty code

(8) Data. Sources

I 4

Fiं.U

I5

I1

10I2

Notes:

(a) in $10^{3} \mathrm{cu} . \mathrm{ft} . / \mathrm{day}$ 
DATA ELEMENT DESCRIPTIONS AND FORMATS

FOR THE FACILITY: NATURAL GAS STORAGE FACILITIES

ELEMENT DESCRIPTIONS

FORMATS

(1)-(3): Identical to those appearing on Table .4

(4) Year

(5) Facility Type

(6) Capacity a

(7) Units of Capacity

(8) . Peak Load Deliverability b

(9) Employment

(10) Certainty Code

I4

Al 0

I6

A10 .

I6

I5

II

$10 \mathrm{I} 2$

(11) Data Sources

Notes:

(a) units are varlable and are given in data item 8 .

(b) in $10^{6}$ cu.ft./day.

\section{TABLE 11}

DATA ELEMENT DESCRIPTIONS AND FORMATS . FOR THE FACILITY: URANIUM MINES

ELEMENT DESCRIPTIONS

(1)-(3): Identical to those appearing on Table 4 .

(4) Year (present or future)

(5) Mine Type a

(6) Present (or planned) Capacity 6

(7) Employment

(8) Certainty Code

(9) Data Sources

FORMATS

Notes:

(a) 1 for open pit, 2 for underground, 3 for in-situ solution

(b) In tons of ore per day 
DATA ELEMENT DESCRIPTIONS AND FORMATS $\because$

FOR THE FACILITY: URANIUM MILLS

ELEMENT DESCRIPTIONS

FORMATS

$\begin{array}{ll}\text { (1)-(3): Identical to those appearing on Table } 4 & \text { I4 } \\ \text { (4) Year (initial operating date) } & \text { Al0 } \\ \text { (5) Process Type } & \text { I5 } \\ \text { (6) Planned Capacity a } & \text { I5 } \\ \text { (7) Employment } & \text { I1 } \\ \text { (8) Certainty Code } & \text { 10I2 }\end{array}$

Notes:

(a) In tons per day

TABLE 13

DATA ELEMENT DESCRIPTIONS AND FORMATS

FOR THE FACILITY: URANIUM ENRICHMENT FACILITIES

ELEMENT DESCRIPTIONS

FORMATS

(1)-(3): Identical to those appearing on Table 4

(4) Year (initial operating date)

(5) Process Type

(6) Planned Canacity a

(7) Employment

(8) Certainty Code

(9) Data Sources

14

A10

I5

I5

I1

1012

Notes:

(a) in tons/year 
TABLE 14

DATA ELEMENT DESCRIPTIONS AND FORMATS

FOR THE FACILITY: ELECTRIC POWER PLANTS

ELEMENT DESCRIPTIONS

FORMATS

(1)-(3): Identical to those appearing on Table 4

(4) Year (current or future planned)

(5) Current ( $\Omega r$ planned) Fuel Type a

(6) Fuel Use b (coal only)

(7) Total Current c (or additional) Capacity

(8) Employment (current or planned)

(9) Certainty Code

(10) Data Sources

I4

I3

14

I4

I5

II

$10 \mathrm{~T} 2$

Notes:

(a) the fuel type codes consist of the following:

$$
\begin{aligned}
& \text { 1- coal } \\
& \text { 2- oil } \\
& \text { 3- natural gas } \\
& \text { 4- hydroelectric } \\
& \text { 5- nuclear }
\end{aligned}
$$

(b) in $10^{6}$ tons/year

(c) in megawatts electric

6- geothermal.

7- combined cycle

8- industrial steam

9- solid waste

\section{TABLE 15}

DATA ELEMENT DESCRIPTIONS AND FORMATS

FOR THE FACILITY: POTENTIAL. GEOTHERMAL FACILITIES

ELEMENT DESCRIPTIONS

FORMATS

(1)-(3): Identical to those appearing on Table 4

(4) Current (or future) Year

(5) Present (or future) Capacity a

I 4

(6) Certainty Code

(7) Data Sources

I1

1012

Notes:

(a) in MWe for electric generation, and number of wells for hot water production. 
TABLE 16

DATA ELEMENT DESCRIPTIONS AND FORMATS

FOR THE FACILITY: SOLAR ENERGY PROJECTS

ELEMENT DESCRIPTIONS

FORMATS

(1)-(3): Identical to those appearing on Table 4

(4) Year

(5) Facility Description

(6) Capacity a

(7) Certainty code

(8) Data Sources

4

A20

I6

il

Notes:

(a) in NWe for powcr plants

\section{TABLE 17}

DATA ELEMENT DESCRIPTIONS AND FORMATS

FOR THE FACILITY: WASTE-TO-FUEL CONVERSION PLANTS

ELEMENT DESCRIPTIONS

FORMATS

(1)-(3): Identical to those appearing on Table 4

(4) Year (initial operating date)

(5) Type and Feedstock

(6) Capacity a

(7) Units of Capacity a

(8) Employment

(9) Certainty Code

(10) Data Sources

I 4

A20

I4.

AI0

I5

II

IOI2

Notes:

(a) units are variable and given in data item 7 .

\section{TABLE 18}

DATA ELEMENT DESCRTPTTONS AND FORMATS

FOR THE FACILITY: OTT, SHAIE PROJECTS

ELEMENT DESGRIPTIONS

FORMATE

(1)-(3): Identical to those appearing on Table 4

(4) Future Year

(5) Mine Type a

(6) Flanincd lapacity L

(7) Employment

(8) Certainty Code

(9) Data Sources

I4

I4

I3

I5

II

IOI2

Notes:

(a) 1 fur slelp, 2 for underground, 3 for in-situ.

(b) in $10^{3}$ barrels/day 
DATA ELEMENT DESCRIPTIONS AND FORMATS FOR THE FACILITY: TAR SANDS PROJECTS

ELEMENT DESCRIPTIONS

FORMATS

(1)-(3): Identical to those appearing on Table 4

(4) Year (initial operating date)

(5) Process Type

(6) Planned Capacity a

(7) Employment

(8) Certainty Code

(9) Data Sources

I4.

Al0

I6

I5.

II.

1012

Notes:

(a) In barrelis/day

\section{TABLE" 20}

DATA ELEMENT DESCRIPTIONS AND FORMATS FOR THE FACILITY: RAILROADS

ELEMENT DESCRIPTIONS

FORMATS

(1)-(3): Identical to those appearing on Table 4

(4) Year (initial operating date)

(5) State Code of Destination

(6) County Code of Destination

(7) Length a

(8) Type

(9) Employment

(10) Certainty Code

(II) Data Sources

Notes:

(a) in miles

\section{TABLE 21}

DATA ELEMENT DESCRIPTIONS AND FORMATS

$\therefore$ FOR THE FACILITY: TERMINAL FACILITIES

ELEMENT DESCRIPTIONS

FORMATS

(1)-(3): Identical to those appearing on Table 4

(4) Year

(5) Farility Type

(6) Fuel Type a

(7) Capacity b

(8) Unlts of Capacity

(9) Employment

(10) Certainty Code

(II) Data Sources

14

I2

I3

14

A10

I5

I1

1012

Notes:

(a) 1 for coal, 2 for o1l, and 3 for natural gas

(b) units are variable and given in data item 8 
TABLE 22

BIOMEDICAL AND ENVIRONMENTAL ASSESSMENT SYSTEM

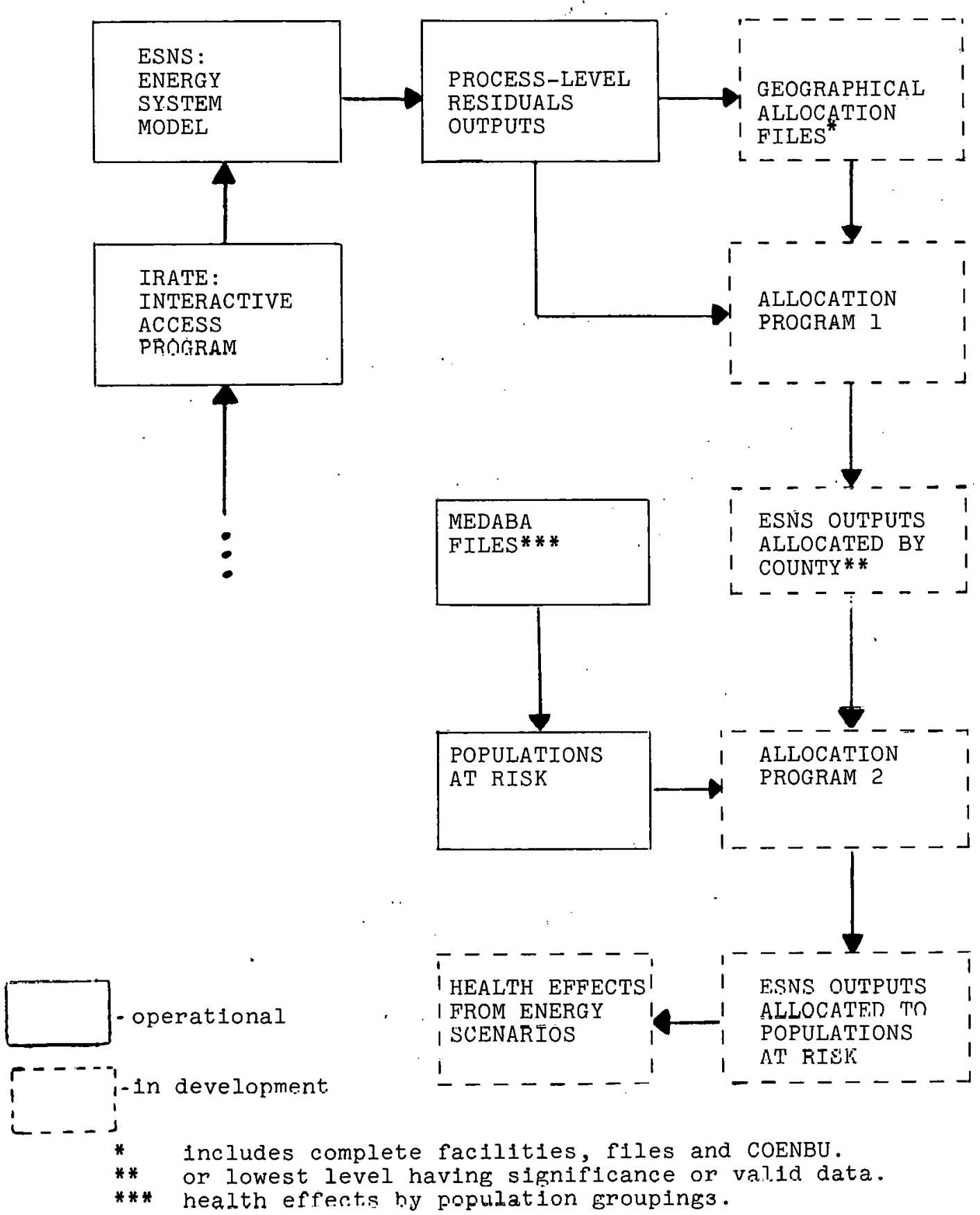




\section{REFFRENCES}

1. Bozzo, S. R. and L. D. Hamilton, Medical data base:

Description and use in energy-related research, Brookhaven National Laboratory, April 1977.

2. Drysdale, F. R. and C. E. Calef, The energetics of the United States of America: An atlas, Brookhaven National Laboratory, BNL Report No. 50501, September 1976.

3. Sevian, W. A., The energy system network simulator: General description and sample analyses, Brookhaven National

Laboratory, BNL Report No. 50492, September 1975 (Draft).

4. Corsentino, J.S., Projects to expand fuel sources in Western States, U.S. Bureau of Mines, Information Circular 8719, 1976.

5. Staff, Eastern Field Operation Center, Pittsburgh, PA, Projects to expand fuel sources in Eastern States,.U.S. Bureau of Mines, Information Circular 8726, 1976.

6. King, L., Editor, The Energy Daily, various issues on file. 